\title{
Female Manipulation in Mahasweta Devi's Breast Giver
}

\author{
M.Niranjana Sundari and M.R Rashila \\ ${ }^{1}$ Research scholar ,Madurai Kamaraj University, Madurai, India. \\ ${ }^{2}$ Research Guide, Head \&t Associate Professor, Sourashtra College, Madurai, Tamil Nadu, India.
}

\section{ABSTRACT}

Mahasweta Devi was an Indian writer.Breast Stories is a collection of three stories authored by Mahasweta Devi, a feminist writer and activist. She is a Bengali leftist intellectual, whose writing is devoted to the struggles of tribal communities. The protagonist, Jashoda, is a marginalized Brahmin woman. After her husband loses both his feet, she is forced to work as a wet-nurse for the wealthy Haldar family. While she is useful, she is deified and revered by the patriarchal society. She is given names like Mother, and Milk-Mother. After she reaches middle age and is no longer useful, she is rejected by the two families, and forgotten by society.

\section{KEY WORDS: TRIBAL WOMEN, MANIPULATION, EXPLOITATION, MEN SUPREMACY, PATRIARCHIAL SOCIETY.}

\section{INTRODUCTION}

Mahasweta Devi is one of India's leading writers. Mahasweta Devi has her distinctive pattern to depict stories from the side of those disregard group of people. Her powerful fiction has won her identification in the form of the different national awards. Mahasweta Devi believes in writing for the genetic, oppressed, and needy. Devi's writing describes the condition of India's aboriginal people and of other economically demean people who were conceived. Devi throws light on female within them with their power and modes of occurrence.

The primary aim of this paper is to highlight the ill effects of the utilization of the women to the core. Devi has written so many short stories exposing the sufferings of women. Among them Breast Giver is the most red remarkable story. In Breast Giver, Jashoda is a middle group Brahmin woman. She is very good and appealing woman. She is the exponent of this story. Her part in this story as a Breast Giver is highly remarkable. Mr.Kangalicharan is the husband of Jashoda who is impotent of maintaining his family because he lost his two legs in an accident. Mr. Haldar, Mrs. Haldar, they are belonging to very rich and big family and having children and grand children. Devi focuses not so much

Biosc Biotech Res Comm P-ISSN: 0974-6455 E-ISSN: 2321-4007
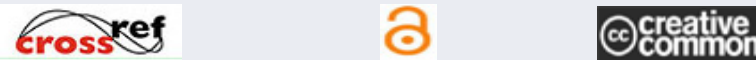

Identifiers and Pagination

Article Information

Year: 2021 Vol: 14 No (8) Special Issue

Received: $08^{\text {th }}$ Apr 2021

Pages: 12-14 Accepted after revision: $18^{\text {th }}$ June 2021

This is an open access article under Creative

Commons License Attribn 4.0 Intl (CC-BY).

DOI: http://dx.doi.org/10.21786/bbrc/14.8.3 on the opposition of the oppressed as on the dynamics of suppression itself. Apparently a member of the highest of the Hindu castes, the Brahmin Kangalicharan is a impotent victim of the rich patriarch Haldarbabu's community who compelled to become the wage earner of the household, Kangalicharan's wife, Jashoda, becomes a wet nurse for the Haldar family, who hold on to her services until she becomes futile to them. Mahasweta's narrative is aimed to exihibit the persistent collusion of patriarchal and capitalist ideologies in the exploitation of the disadvantaged. Themselves victims, the women of the Haldar household are Jashoda's chief exploiters. The position of wage earner not only fails to free Jashoda from the expectations of wifehood and motherhood but burden her with the ultimately self destructive work of being "mother of the world". Nevertheless, neither victimization nor its awareness completely steals Jashoda and Kangalicharan of their sense of agency and potential.

Jashoda, the principal character in "Breast -Giver", is a working woman or, as the narrator puts it, "professional mother". As translator Gayatri Spivak has pointed out, in the story's title the writer deliberately foregrounds the centrality of the female body in Jashoda's deals with her clients -she is not just a "wet nurse" a provider of milk, but a "breast giver", a difference further under scored by the dismal ironies that unfold in the narrative of her career. The tale gives new routes for examining the points at which gender and class suppression intersects. Not only is Jashoda the breast -giver named for Yashoda, the mother of the beloved cowherd-child-god Krishna, but in the course of the narrative the professional mother integrates with other Indian statues of motherhood 
-sacred cows, the Lion -seated goddess, "mother India" herself.

In her story, The Breast Giver, from her collection of short stories called, Breast Stories, Mahasweta Devi demarcates women's recognition as body, worker and object. Jashodha is swiftly utilized and praised for her expert weaning of wealthy offspring which she dose for twenty five years before losing her usefulness and consequentially dying from breast cancer. Lacanian and Freudian psychoanalytic criticism could be used to support the state that the central theme of this story involves a discussion between the spiritual importance of woman and her place in the imaginary order. The desires of man as they become dominant in the symbolic order and the law of the father originate in a foreign language, setting and cultural context given to maintain a clarity and relevance of symbolism. Haldar assures his victim “Don’t worry, son! You won't suffer as long as I'm around'.

Thought this promise comes as a relief to the now mutilate priest, it is not him whose survival is truly threatened -he is after all of the highest caste in what Devi calls in her story",......independent India, the India that makes no differentiations among people.... Varieties of Brahmin..." Even though Haldarbabu makes his fortune in the British era of "divide and rule" he says, "There's no East or West for a Brahmin".Without his feet Kangali's security is mostly guaranteed by his spiritual standing. The lady of the house decides that this scheme of utility is "worth a million rupees" because daughter-in-laws will be mothers. And most significantly, will be mothers for as long as possible, even though continuous suckling will "ruin a mother'Ts shape".If sons look outside there is no voice to object. "Going outside because they can't get it at home, this is just", the mistresses statement. As the wife, through her gift of reproduction becomes objectifiedin the market as commodities, and her husband as a consumer expects an endless supply to satisfy his insatiable almost childlike desire for both "trophyand tool", the wife knows, as a woman she must take on the minor role of simultaneously requesting and producing for her masters."Such is the power of the Indian soil that all women turn into mothers here and all men remain immersed in the spirit of holy childhood", writes Devi. This theme of suppressive dominion built into both spiritual practice and economic belief, resonates in all of the narratives of the women in, "Breast Stories".

In the "Breast Giver", as Jashoda becomes more and more revered for her body's other worldly tolerance, it seems as though the twofold is moving towards free play -from man /woman to a hierarchy closer to woman/ man. Both Brahmans in their own right, Kangali shares home works as he takes on the cooking at home and cares for their three children as Jashoda is heralded as a wet-nurse and, "the mother of the world".Jashoda's only usefulness in the male dominated cultural background is her maternal plenitude, her duty of raising children out of an imaginary order as she dives into the symbolic law of the father. This "usefulness" is the responsibility of all mothers of patriarchy.

As she extends her work to countless children, other than her own, Jashoda becomes "Martyr"-a role that suggests both significance and sub-ordinance, and even worship, while she simultaneously secures her "never ending" lack of milk and nourishment.That she willingly keeps emptying herself for the "good of man囚 makes it possible to regard her without ultimately amend her under privileged charge. Devi suggests the divine is in many ways just another phallus for the "law of the father". Jashoda is not seen as constitutionally divine as Kangali. She only becomes so when she has a service to give or when thelast child is weaned and her supporting mistress dead. At the end, she is left to weep at the lionseated feet with a pained and cracked bosom.In the end, no prophetic dream comes to guide her;no benefactor looks at her state and runs to help her divine grace. Her body is revealed as a mere vessel that man through his religious symbols prods on. Once used for her will and now left empty and lacking, Jashoda suffers a painful and sickened death. Her plentiful breasts now become a enormous wound.

Jashoda who lives the life of sacrifice for husband and owner's family. In "Breast Giver",Jashoda is employed as a professional mother in an upper class Brahmin household to support her crippled husband, Kangali". The argument is about existence with own body which takes care husband and gets a professionalized identity. Mahasweta Devi wants to value Jashoda with her strength of self that "she wants to become the earth and feed her crippled husband and helpless children with a fulsome harvest"in this way Jashoda is also presented as the figure of mother India, "such is the power of soil". Jashoda is localized in terms of her needs and existence. It is the fact that Jashodo's reproductive body which turns out to be the source of earning livelihood not for her but for her husband and her children. The breast milk is valuable part of existence which nourishes the upper-class Haldar household. Her bodily performance becomes the major source of income for Jashoda's crippled husband.

In this paper, it will be attempted that the growth of those people who are realising on their ways of living without being compared to higher class of people. Devi have tried to find the power of resistance and bodily acts of those shadowed females. It is reflected in their manner of acceptance and the collective consciousness in regard to their social position. In this subaltern location, females are having their position within the boundary of their family needs and survival forces. The female modes differ for locating the female identity. They grow with their power of resistance as they use their bodily per formative acts as means of devaluing the power existence. Spivak uses the "Breast Stories" of Mahasweta Devi to explain the position and real existence of female in the context of the unheard situation of the group. Jashoda in Mahasweta Devi's 
story "Standayini (Breast Giver)," makes her presence and existence as breast feeder and a source of survival for her crippled husband. They grow with the strength of resisting the power politics without revolt. In this mode female struggle and resistance, feminism gets different outlook as for localized female version of identifying themselves.

People need to refer the feminisms which raise the problem of gender as the basis for the organization of society; there were various debates and struggle in female movements. The basic component in every modes of female identity formation is heading forth for equality with male or for establishing the differences with men. These modern trends have brought female right debates rather than to trace out true identity. In female movements they get liberal females who search for equal rights and radical females who insisted the differences as their identity marker. In every steps of female discourse people find the attempt to get political visibility in the world. Female experience is engraved in the female subject. As said before, women in (post) colonial cultures have been termed "the twice colonized", both by the imperial and the male social order. As such, women and the colonize dare seen as sharing an experience of suppression and downtrodden that has built their very beings. This mode of female essence makes the way for discussing about the subaltern group.

It is noticed identity formation in terms with cultural, ethnical or any other social marker but their own silent way of manners, rumors and collective efforts. It could be seen as resisting and rebuilding modes where they either live with a communal mode or as simplemindedness behaviour just bothering their own periphery. This paper will justify that subaltern female existence is built with more reverent stature which makes the people in power worthless. Traditionally, the daughters of a family marry and move into their husband's house, which includes his entire family. Daughter-in-laws help their new family by managing the household and providing heirs to the family. The story says, "Each man the Holy Child and each woman the Divine Mother". The women are mothers and extend their husband's family lineage. The families in India, the wives are mostly housewives who take care of their children, elder relatives, and parents. Even with the Indian families some of the wives graduated with college degrees and held jobs for a few years, but when they had children many of them quit their jobs and became stay at home mothers.

The class believed that Jashoda was exploited through her profession because she was a woman, and that the Haldar family was using Jashoda's body for their use. However, believe that Jashoda was exploited because of the class structure. To a certain extent, the Haldar household was using Jashoda's body, but religion and culture also helped others realize that her new profession is a positive milestone in her life. The female body has the reproductive system to nurture and rear children, and Indian women are seen mostly as mothers, by profession. Jashoda is not exploited because she is a woman; instead, she is exploited because of the class structure and the change of time and the circumstances lead to her puzzling fate. The culture and religion help represent Jashoda's profession positively. Jashoda has a dream where the Lion seated comes to her as a midwife. At first, the interpretation of the dream is confusing; however, when Jashoda accepts her profession at the Haldar household, people in the neighborhood, Astrology, dreams, and spiritual connections with the gods and goddesses are taken very seriously in the Indian culture;

It is pictured in the story, "Thus even the skeptics were persuaded that the Lion seated had appeared to Jashoda as a midwife for this very reason". The Lion seated coming into her dream is a very important sign that shows she is not being subjugated or used by others because she is a woman who can rear children, but that it was her fate chosen by God. The story also mentions that "Faith in the greatness of the Lion seated was rekindled in the area and in the air of the neighborhood blew the electrical fying influence of goddess-glory”. Jashoda helped to get back the faith in the Lion seated. She represented a living form and the glory of the Lion seated, and because of that "everyone's devotion to Jashoda became so strong that at weddings, showers, naming, and sacred-threading they invited her and gave her the position of chief fruitful woman". Her connection with the Lion seated lifted her status and made her significant in the neighborhood. Inviting, Jashoda is similar to inviting the Lion seated. Even the children who were reared on Jashoda's milk were called the Holy Children. This helped the status of the Haldar children and her own because they were seen as the ones who suckled from the Holy Mother. Atleast, in the fore coming years women folk hopes to live in a healthy ideological society peacefully.

\section{REFERENCES}

https://www.ijsr.net/archive/v9i2/SR20211113132.pdf http://briancroxall.pbworks.com/f/Devi-BreastGiver. pdf

https://www.gradesaver.com/mahasweta-devi-shortstories/study-guide/character-list

https://feminisminindia.com/2019/02/08/draupadireview-mahasweta-devi/

https://www.thecuriousreader.in/features/mahaswetadevi-draupadi/ 